\title{
A POLÍTICA DE ACESSO À TERRA NO BRASIL IMPERIAL E A COMPRA DE TERRAS DEVOLUTAS NO PLANALTO DA PROVINCIA DE SANTA CATARINA
}

\author{
Paulo Pinheiro Machado* \\ Flávia Paula Darossi**
}

\begin{abstract}
RESUMO: Este trabalho objetivou apresentar uma breve discussão historiográfica sobre a política de terras no Brasil Imperial, e o estudo relacionado à aplicação da Lei de Terras na província de Santa Catarina (Lei N ${ }^{\circ} .601$ de 18 de Setembro de 1850 e Decreto $N^{\circ} .1318$ de 30 de Janeiro de 1854 que regulamentou a execução da Lei), com ênfase no município de Lages e nas freguesias de Curitibanos e Campos Novos (emancipadas da jurisdição lageana durante as últimas décadas do século XIX). O estudo foi realizado com base em requerimentos de compra de terras devolutas, lavrados entre 1850 e 1889, previstos na legislação como a única forma legal de acesso à terra. Por tratar-se de uma fronteira agrícola e de povoamento em expansão, nos anos oitocentos, o planalto catarinense foi ocupado de diferentes maneiras - que ultrapassavam as disposições da própria Lei -, o que repercutiu em complexas estratégias de regulamentação da propriedade.
\end{abstract}

PALAVRAS-CHAVE: Historiografia; Império do Brasil; Política fundiária; Planalto Catarinense.

\section{The land access policy in Imperial Brazil and the purchase of devolutas lands in the provincie of Santa Catarina Highlands}

ABSTRACT: This paper aimed to present a brief historiographical debate on land politic in Imperial Brazil, and the study related to the implementation of the 1850 Land Law in the province of Santa Catharina Plateau(Law No. 601 of September 18, 1850 and Decree $N^{\circ} .1318$ of January 30, 1854 which regulates the implementation of the Law), with emphasis in Lages and in the parishes of Curitibanos and Campos Novos (emancipated of the jurisdiction of Lages during the last decades of the nineteenth century). The study was conducted based on purchasing requirements of devolutas (vacant) lands, produced between 1850 and 1889 , provided by the law as the only legal form of access to land. As an agricultural frontier and population expanding, in the nineteenth century, the Santa Catarina Plateau was occupied in different ways - that go beyond the provisions of Law -, which reverberated in complex regulatory strategies of the property.

KEYWORDS: Historiography; Empire of Brazil; Land policy; Santa Catarina Plateau.

\section{La política de acceso a la tierra en el Brasil Imperial y la compra de terrenossin dueños en la Meseta de la provincia de Santa Catarina}

RESUMEN: Este trabajo tuvo como objetivo presentar un breve debate historiográfico sobre la política de la tierra en el Brasil Imperial, y el estudio relacionado con la aplicación de la Ley de Tierras de 1850, en la provincia de Santa Catarina (Ley N ${ }^{\circ} .601$ de 18 de septiembre 1850 y el Decreto $n^{\circ} .1318$ de 30 de enero 1854 que regula la aplicación de la Ley), con énfasis en Lages y en las parroquias de Curitibanos y Campos Novos (emancipado la jurisdicción lageana durante las últimas décadas del siglo XIX). El estudio tomó por base a los requerimientos de compra de los terrenos sin dueños, emitidos entre 1850 y 1889, que se establecen en la legislación como la única forma legal de acceso a la tierra. Como se trataba de una frontera agrícola que experimentabauna expansión de población, en losochocientos, la meseta de Santa Catarina fue ocupada de diferentes maneras - que van más allá de las disposiciones de la Ley -, lo que tiene como efecto el surgimiento decomplejas estrategias de regulación de propiedad.

PALABRAS CLAVE: Historiografía; Imperio del Brasil; política de la tierra; Meseta de Santa Catarina.

\footnotetext{
*Doutor em História pela Universidade Estadual de Campinas, Brasil(2001). Diretor do Centro de Filosofia e Ciências Humanas da Universidade Federal de Santa Catarina. E-mail: paulo.pinheiro.machado@ufsc.br

**Mestranda do Programa de Pós-Graduação em História pela Universidade Federal de Santa Catarina. Email: $\underline{\text { flavia.darossi@gmail.com }}$
} 
Em um requerimento de compra de lote de terra devoluta da freguesia de São João dos Campos Novos dirigido a Francisco Carlos de Araújo Brusque, presidente da província de Santa Catarina em 1859, consta que:

[...] EIle, Supplicante, além do seo mizeravel estado de pobreza, acha-se circundado de numeroza familia, e todos menores; occorrendo, para mais cumulo de sua infelicidade! não ter o Supp.e terras de cultura onde trabalhe para do produto tirar ao menos á subsistência para si e sua numeroza familia. E como constasse ao Supp.e que o Governo Imperial, por um acto de Ana magnitude, authorizou a V. Ex $x^{\mathrm{a}}$. para vender lotes de terras devolutas pelo preço de meio real a braça quadrada a algumas familias mizeraveis d'esta Freguesia [?] e achando-se o Supp.e n'estas tristes circunstâncias [?] vem submissamente imputrar a V. Exa . queira conceder-lhe um lóte de terras de cultura, nas mattas devolutas [...]. ${ }^{1}$

O requerente, analfabeto, declarou viver em condição de pobreza e a privação de terras próprias para o trabalho na lavoura e para a subsistência de sua família, e deduziu que seu estado de miserabilidade lhe facultaria o direito de acesso à terra pelo menor preço proposto pela Lei de Terras. Seu apelo evidencia a imagem paternalista conferida ao governo e à legislação imperial. A solicitação foi deferida por Araújo Brusque, e arbitrado pela Tesouraria da Fazenda Pública da província o preço de dois réis à braça quadrada de terra, custo mais oneroso que o proposto no requerimento.

A historiografia sobre políticas fundiárias no Brasil ainda é bastante marcada por uma visão clássica que compreende a legislação agrária como a expressão jurídica dos interesses de grandes proprietários de terras atrelados ao poder central. Parte-se do pressuposto de que a Lei de Terras de 1850 foi criada apenas para assegurar os interesses da classe dominante, constituindo-se como um marco no processo de apropriação capitalista do Brasil. Deste pensamento estatista desenvolveu-se grande parte dos estudos sobre a questão agrária no país. ${ }^{2}$

O sociólogo José de Souza Martins consagrou a ideia de que a Lei de Terras no Brasil consolidou a propriedade privada ao determinar juridicamente a compra de terras como única forma de acesso legal à propriedade, "impedindo" a ocupação de terras devolutas pela população na transição do regime de trabalho escravo para o livre. ${ }^{3}$ Já o historiador José Murilo de Carvalho salientou a desconsideração da classe proprietária frente à política de regularização fundiária que, "vetada pelos barões", 4 fracassou no intento de discriminar as terras públicas das particulares, ao propor limites à expansão territorial de grandes senhores $e$ possuidores de terras. ${ }^{5}$ 
Ambas as perspectivas contribuíram para elucidar aspectos da Lei, mas não contemplam a complexidade da conjuntura histórica de sua produção como tampouco das relações sociais constituídas no jogo de forças para sua aplicação; que permitiram diferentes interpretações acerca do direito à terra, a exemplo do requerimento do posseiro da freguesia de São João dos Campos Novos, deferido por Araújo Brusque em 1859.

Em um artigo sobre as distintas interpretações da Lei de Terras, Márcia M. M. Motta afirma a importância da análise histórica acerca dos diferentes processos de apropriação territorial e de regularização fundiária no Brasil do século XIX, visto que

Séculos de formas de ocupações diversas, com diferentes e conflitantes interpretações sobre o direito à terra, somadas às incessantes tentativas de regularização fundiária, haviam ajudado a construir uma sociedade agrária, na qual a possibilidade de manter a posse sobre uma parcela de terras era algo que envolvia um jogo de interesses bastante complexo, no qual as relações sociais eram utilizadas para legitimar o direito à área ocupada. ${ }^{6}$

Em conformidade com Motta, o antropólogo James Holston enfatiza que a História deve questionar o princípio da lei como instituição absoluta - cuja função, em tese, seria manter as condições necessárias à vida social -, visto que, na prática, existe uma discrepância entre a lei formal e a lei aplicada.Para o autor, a legislação é construída a partir de um campo de disputas entre grupos divergentes, e o sentido da justiça submete-se a circunstâncias factuais e não a normas fixas. ${ }^{7}$

Também o historiador Edward P. Thompson argumenta que as leis expressam diferentes valores e implicações por vezes variadas no domínio prático, e por isso necessitam ser compreendidas historicamente no campo de sua própria gestação e aplicação. Apesar de reconhecer o caráter classista das mesmas, o autor afirma que a forma e a retórica das leis adquirem identidades maleáveis e por vezes sui generis quando apropriadas num discurso e contexto específicos, e apresentam diferentes possibilidades que, "às vezes, inibem o poder e oferecem alguma proteção aos destituídos" que lutam no campo jurídico. ${ }^{8}$

A partir desta perspectiva, torna-se possível problematizar a interpretação do requerente de Campos Novos sobre a Lei de Terras, visto que, ao citá-la como um ato de benevolência do imperador, utilizou como argumento a possibilidade de concessão de lotes de terras devolutas a preços baixos para famílias em condição de extrema pobreza quando, juridicamente, o preço era arbitrado conforme a qualidade e a situação das terras, independentemente de quaisquer fatores sociais. 
Na obra intitulada Tierras, Leyes, Historia: "estudios sobre la gran obra de la propiedad" a historiadora Rosa Congost critica a historiografia estatista espanhola contemporânea e afirma a necessidade de desconstruir a concepção moderna de que a ocupação do espaço e a propriedade fundiária formam-se única e exclusivamente de acordo com as leis agrárias promovidas pelo Estado. Compreender a propriedade a partir desta versão reforça a concepção de poder absoluto do Estado frente às relações sociais e as leis, o que redunda em uma abstração que não condiz com a realidade histórica.

Em consonância com Holston, Thompson e Motta, Congost propõe a análise da formação da propriedade compreendida enquanto resultado de relações sociais específicas, a partir das diferentes formas de ser proprietário, seja pelo direito costumeiro ou positivo:

\begin{abstract}
Analisar as condições de realização da propriedade [que podem ser muito diversas] é algo muito diferente de analisar o marco jurídico ou institucional de uma sociedade [...]. Não nos interessam apenas as condições legais da propriedade, mas o conjunto de elementos relacionados com as formas diárias de ligação com os recursos, com as práticas diárias da distribuição social da renda, que podem condicionar e ser condicionados pelas diferentes formas de disfrutar dos chamados direitos de propriedade, e também pelos direitos e práticas de uso, ou seja, pelas diferentes formas de ser proprietário. Passar da propriedade como ideia para a ideia da propriedade como obra, e como obra em contínua construção [...].Uma sociedade, ademais, que por definição, se acha em constante movimento e em que podem produzir-se rupturas importantes nas formas de disfrute dos direitos de propriedade, embora anteriormente não se tenham produzido mudanças significativas no marco político e jurídico. ${ }^{10}$ Livre tradução.
\end{abstract}

O objetivo de tais proposições é atinar para a importância da atuação humana na construção do marco jurídico da propriedade, minimizando a ênfase em explicações que tendem a naturalizar o status quo, haja vista que a lei e as políticas de Estado nunca são sentidas da mesma maneira pelos diferentes grupos sociais. Compreende-se que era a partir da grande política nacional que a população agenciava suas estratégias de acesso à propriedade, seja sob a forma de acatamento, resistência ou conflito para a região em que estava circunscrita; a partir de diferentes condições e relações sociais que extrapolavam a legislação fundiária.

No livro Terra Prometida, um dos precursores da história agrária e do campesinato no país,Maria Yedda Linhares e Francisco Carlos Teixeira da Silva enfatizam a necessidade de tornar históricas as diferentes formas de propriedade, e destacam a contribuição de Karl Marx no que se refere às relações de dominação dos indivíduos com o meio natural:

As relações entre os homens e a natureza eram, para [Karl] Marx, ponto fundamental para a compreensão das origens das desigualdades sociais. Com isso, 


\begin{abstract}
Marx queria se referir às relações existentes entre as condições materiais, objetivas, da existência humanas e às formas desenvolvidas pelos homens para sua apropriação. Tais formas de apropriação da natureza - a terra, as águas - foram diversas ao longo da existência [...], com características específicas de cada cultura e de cada época. Logo, Marx estabelecia o caráter histórico, quer dizer, transitório das formas de propriedade da terra [...], negando um estatuto de naturalidade à propriedade. Tais formas de apropriação das condições materiais de existência engendraram relações sociais específicas entre os homens, em especial quando uns tinham o monopólio sobre os bens naturais e os demais ficavam excluídos de seu gozo. $^{11}$
\end{abstract}

No Brasil, a legislação fundiária proposta pelo Império na primeira metade do século XIX indica que latentes transformações nas formas de ocupação da terra e nas relações de trabalho estavam sendo tratadas como problemas de Estado. A Lei de Terras de 1850 resultou da disputa e do debate parlamentar entre liberais e conservadores que visavam, a partir de diferentes propostas legislativas, solucionar conflitos que envolviam a ocupação do território nacional.

É importante ressaltar que o liberalismo brasileiro dos anos oitocentos possui um caráter bastante específico por ter sido imbuído de um ideário extremamente conservador no que concerne ao projeto administrativo do país. Segundo Alfredo Bosi, crítico e historiador de literatura brasileira, a antinomia entre este caráter liberal e a ideologia conservadora do país presente na construção do Estado Nacional resultou na produção de um conjunto jurídico que evidencia o processo pelo qual grandes senhores e possuidores de terras, escravos, engenhos e fazendeiros de café, articulados na esfera do poder imperial, intencionaram uma política funcional que garantisse seus direitos individuais e a propriedade fundiária, a manutenção da escravidão, da grande produção e o modelo agroexportador. ${ }^{12}$

A análise sobre o direito e a política fundiária promovida no século XIX é de substancial relevância, considerando ser sua jurisprudência o instrumento que norteava - do ponto de vista legal - o funcionamento da sociedade e da ocupação da terra no país. Em uma comunidade demasiadamente hierarquizada e desigual como era o Império do Brasil, os diferentes grupos se articulavam à legislação conforme suas relações sociais os permitiam, enquadrando o direito e a justiça aos seus interesses classistas mediados através de uma ideologia reforçada pela articulação política.

James Holston afirma que a legislação fundiária brasileira foi gestada por imposições políticas que tencionavam legalizar usurpações praticadas por grandes senhores e possuidores de terras atrelados a esfera de poder imperial. ${ }^{13}$ Este caráter conciliatório da Lei de Terras para a legitimação de grandes apossamentos foi apontado pela historiadora Lígia 
Osório Silva, na obra Terras devolutas e latifúndio: efeitos da lei de 1850. A autora observa que grandes posses eram legitimadas independentemente da extensão e da data de ocupação, o posseiro caído em comisso, ou seja, aquele que não cumpria as disposições legais acerca da propriedade, continuava na posse das terras, e o imposto territorial previsto no projeto anterior da Lei de Terras, de 1843, foi vetado; evidenciando como o conservadorismo contribuía sobremaneira para a manutenção da concentração fundiária no país. ${ }^{14}$ Neste sentido, Holston afirma que

A própria lei da terra se desenvolveu, em grande medida, a partir da necessidade de legalizar invasões. Esse desenvolvimento redundou numa densa massa de complexidades jurídicas, por sua vez gerada como uma estratégia para iniciar manobras extrajudiciais, visando precipitar a legalização das invasões [...]. Assim como ocorre hoje, as invasões ajudavam os mais pobres a ganhar acesso à terra, já que, de acordo com os direitos consuetudinários, eram reconhecidos como proprietários legítimos se fossem produtivos. Apesar dessa mistura de lei e costume ajudar os mais humildes, ela também permitia, e numa proporção maior, aos grileiros camuflar suas fraudes dentro de uma rede e transações legítimas, legalizando o ilegal. ${ }^{15}$

Assim, "a lei de terras no Brasil promove conflito, e não soluções, porque estabelece os termos através dos quais a grilagem é legalizada", ${ }^{16}$ tornando-se instrumento de manipulação pelo qual todos procuravam validar seus interesses. As distinções entre o legal e o ilegal seriam temporárias, e práticas ilegais como a ocupação de terras devolutas sem o devido título de concessão produziram leis, haja vista o artigo $5^{\circ}$ da Lei de Terras, que previa a legitimação de posses "mansas e pacíficas, adquiridas por ocupação primária [...] que se acharem cultivadas, ou com princípio de cultura, e morada habitual do respectivo posseiro", ${ }^{17}$ até data anterior a da promulgação da referida lei, quando o artigo $1^{\circ}$ determinava que "ficam proibidas as aquisições de terras devolutas por outro título que não seja o de compra". ${ }^{18}$ Como o Governo Provincial poderia definir quais terras públicas estavam aptas a ser alienadas se os prazos de legitimação de antigas posses e, portanto, o acervo de terras já possuídas, ainda não estava definido?

Como o fazem Holston e Osório Silva no que concerne à Lei de Terras, Rosa Congost observa que a dinâmica social da propriedade implicava a transformação e a criação de novos direitos de propriedade - que muitas vezes não dispunham de seguridade jurídica no momento de sua realização ${ }^{19}$-, a exemplo de ocupações de terras devolutas à revelia nos períodos colonial e imperial, e indica a transformação dos próprios grupos sociais envolvidos quando estes novos direitos passavam a ser reconhecidos, alterando os próprios padrões de hierarquia social. 
A História Social da Propriedade questiona a grande política e a história através de estudos de caso pela análise de séries documentais e o esforço historiográfico comparativo, contemplando os mecanismos da transformação no tempo a partir da complexidade da realidade histórica. A ambiguidade existente entre alguns dos artigos que compõe a Lei de Terras redundou na possibilidade de divergentes interpretações sobre o direito à terra, muito em função de diferentes formas de ocupação territorial e direitos costumeiros praticados.

A partir da realidade multifacetada dentre as vinte províncias do Império do Brasil, bem como dos distintos propósitos e apropriações da legislação pelos diferentes grupos sociais nos anos oitocentos, podemos considerar a assertiva do historiador Giovanni Levi cabível ao caso da política imperial brasileira, quando ele destaca a microanálise como o meio mais construtivo de pensar a História Social, no sentido de viabilizar um olhar atento sobre as brechas do sistema legal e a compreensão de ambiguidades no direito positivo. $\mathrm{O}$ autor sugere "uma investigação da extensão e da natureza da vontade livre dentro de uma estrutura geral da sociedade humana [...]," ${ }^{20}$ na qual toda a ação social é compreendida enquanto resultado de constantes negociações e escolhas dos indivíduos "diante de uma realidade normativa que, embora difusa, não obstante oferece muitas possibilidades de interpretações e liberdades pessoais". ${ }^{21}$

Com base no estudo intensivo de séries documentais, a análise microhistoriográfica propõe a observação de elementos variáveis presentes na regularidade das fontes, bem como sua leitura acurada. Segundo Carlo Ginzburg, precursor da micro-história juntamente com Levi, a análise deve ser bifronte: para além da análise serial, propõe-se indagar, a partir da escala reduzida no trabalho com as fontes, as estruturas invisíveis dentro das quais a realidade dos atores sociais se articula. ${ }^{22}$ Assim, dá-se relevância ao que era por vezes considerado estatisticamente irrelevante ou exceção, nos permitindo questionar e problematizar perspectivas lineares, estatistas e generalizantes presentes na historiografia acerca do tema em questão.

Desta forma, a História Social da Propriedade precisa desnaturalizar a concentração da propriedade no país, e problematizar a política de regularização fundiária construída no período monárquico. Dever-se-á compreender a complexidade social do mundo agrário do Brasil meridional no referido período: caboclos, pequenos, médios e grandes posseiros, lavradores e/ou proprietários nacionais, vindos de províncias vizinhas, imigrantes europeus e descendentes, assim como diferentes etnias indígenas inseridas num campo de forças cujo cenário abrigava relações de alteridade horizontais e verticais tanto pelo usufruto 
eposse útil da terra quanto por sua propriedade legal, articuladas ou não à esfera judicial. Márcia Motta afirma que conflitos pela terra revelam uma sociedade complexa, plural e multifacetada, que não era apenas formada pelos binômios senhor-escravo ou fazendeiroposseiro. ${ }^{23}$ Segundo ela, um pequeno posseiro nunca era um fazendeiro, mas um fazendeiro era ou poderia ser um grande posseiro. ${ }^{24}$

O próprio campo da História Agrária no Brasil compreende vasto conjunto de fontes referentes à burocracia imperial. A história social da propriedade propõe relacionar a análise de diferentes documentos e compreender questões de ordem política, econômica e social como fatores que contribuem na dinâmica da transformação da terra em propriedade. $\mathrm{O}$ ponto fulcral é perceber como estes diferentes fatores se articulam na realidade vivida e no agenciamento social, para além da legislação vigente;considerada,portanto, apenas parte da análise da dinâmica histórica da regularização fundiária.

Segundo o historiador Jacques Revel, deve-se estudar a sociedade "não como um objeto dotado de estruturas e propriedades, mas sim como um conjunto de inter-relações móveis dentro de configurações em constante adaptação". ${ }^{25}$ Neste sentido, Giovanni Levi enaltece que a aplicação da lei e a jurisprudência devem ser analisadas com base nas estratégias sociais concernentes, ou seja,

\footnotetext{
Os micro-historiadores concentraram-se nas contradições dos sistemas normativos e por isso na fragmentação, nas contradições e na pluralidade dos pontos de vista que tornam todos os sistemas fluidos e abertos. As mudanças ocorrem por meio de estratégias e escolhas minuciosas e infinitas que operam nos interstícios de sistemas normativos contraditórios. Isto é realmente uma reversão de perspectiva, pois acentua as ações mais insignificantes e mais localizadas, para demonstrar as lacunas e os espaços deixados em aberto pelas complexas inconsistências de todos os sistemas. ${ }^{26}$
}

Assim, condicionada pela análise micro historiográfica, a História Social da Propriedade procura analisar a legislação fundiária de forma questionadora, bem como a propriedade enquanto construção social, uma vez que os procedimentos desenvolvidos para a anuência da expedição do título definitivo de propriedade não foram realizados da mesma forma pela população no período monárquico.

\section{Ocupação e regularização fundiária no Planalto de Santa Catarina e a administração da Lei de Terras de 1850 na província}

A dimensão histórica do conceito de propriedade possui caráter dinâmico e conjuntural, e seu estudo a partir do planalto catarinense é importante porque evidencia o 
processo de construção da estrutura agrária regional, mediado através dos complexos agenciamentos sociais e políticos que envolveram o uso e a posse da terra, seu domínio e regularização. Por isso, faz-se necessário desnaturalizar o binômio "pecuária-latifúndio" no sentido de repensar os padrões de ocupação da região, e considerar a multiplicidade de forças produtivas e de subsistência existentes.

Habitada por populações indígenas das etnias Xokleng e Kaigang, a região do planalto catarinense foi colonizada por bandeirantes e tropeiros paulistas a partir do início do século XVIII, ${ }^{27}$ constituindo parte do caminho das tropas de muares conduzidas do território platino até a província de São Paulo. Datam deste período as primeiras concessões régias de sesmarias para pecuaristas paulistas na região, onde foram estabelecidas fazendas de criação e invernada de gado.

O governo da Capitania de São Paulo fundou a Vila de Nossa Senhora dos Prazeres do Sertão das Lagens em 1771. O objetivo era reunir a população de fazendeiros e pecuaristas que já existia dispersa pelo planalto, ampliar rotas de transporte terrestre pelo interior e garantir a defesa do território português contra possíveis ataques castelhanos.

Lages teve sua fundação e seu desenvolvimento econômico condicionados pela atividade pecuária, visto que se constituiu como rota de abastecimento com a produção, o comércio e o transporte de gado vacum, cavalar e muar para províncias adjacentes atreladas ao mercado agroexportador. A ocupação e a concentração de vastas extensões fundiárias por grandes criadores e fazendeiros foram promovidas desde as primeiras concessões sesmariais. Isto evidencia a importância deste mercado regional para a economia colonial. Segundo Paulo Pinheiro Machado, “as áreas variavam de 5 mil a 20 mil hectares, reproduzindo no planalto serrano o mesmo padrão latifundiário dominante no Brasil". ${ }^{28}$

Existia maior facilidade para a prática de apossamentos em regiões de fronteira interna aberta e com baixa densidade demográfica como no planalto no início do século XIX. Além disso, a região contava com uma estrutura estatal ainda em construção, concomitante ao agravante de estar sob disputa jurídica pelas províncias do Paraná e Santa Catarina acerca da jurisdição dos limites. ${ }^{29}$

Como área de colonização marcada pelo movimento de expansão demográfica durante o período que compreende a presente pesquisa, o planalto contou com o estabelecimento de uma significativa população de pequenos e médios lavradores independentes, sobretudo a partir da segunda metade do século XIX, em áreas devolutas de florestas e faxinais às margens de rios e grandes propriedades pastoris, principalmente no 
planalto médio e norte, "nos vales dos rios Marombas, Taquaruçu, Paciência, Canoinhas, Timbó, Peixe e Iguaçu, regiões a oeste e a norte de Curitibanos", ${ }^{30}$ provenientes de São Paulo, Paraná (a partir de 1853) e do Rio Grande do Sul. ${ }^{31}$ Trabalhavam na agricultura de subsistência com a produção de culturas de primeira necessidade como milho, feijão e trigo, fumo, criação de animais como gado, mulas e suínos, extração de erva-mate para beneficiamento doméstico e/ou a venda de excedentes para tropeiros em trânsito, para pequenas casas comerciais da própria região ou para a sede da província. A respeito de Curitibanos, Zélia A. Lemos afirma que:

[...] Surgiram depois de 1800, pequenas posses de terras, ao longo da estrada geral e para o interior, que depois foram registradas na câmara de Lages. O sistema de posse consistia na queima de um pedaço de campo, onde o posseiro tratava logo de se estabelecer com um rancho, ou ao menos um curral para o gado e a pequena roça; era esse o meio de assegurar a posse que vigorou até mesmo depois da república. Mas a posse não era uma fazenda; as fazendas eram enormes e para formá-las, os fazendeiros vindos de fora compravam essas terras e depois ampliavam seu território com apossamento de terrenos vizinhos ou por compra de várias posses. ${ }^{32}$

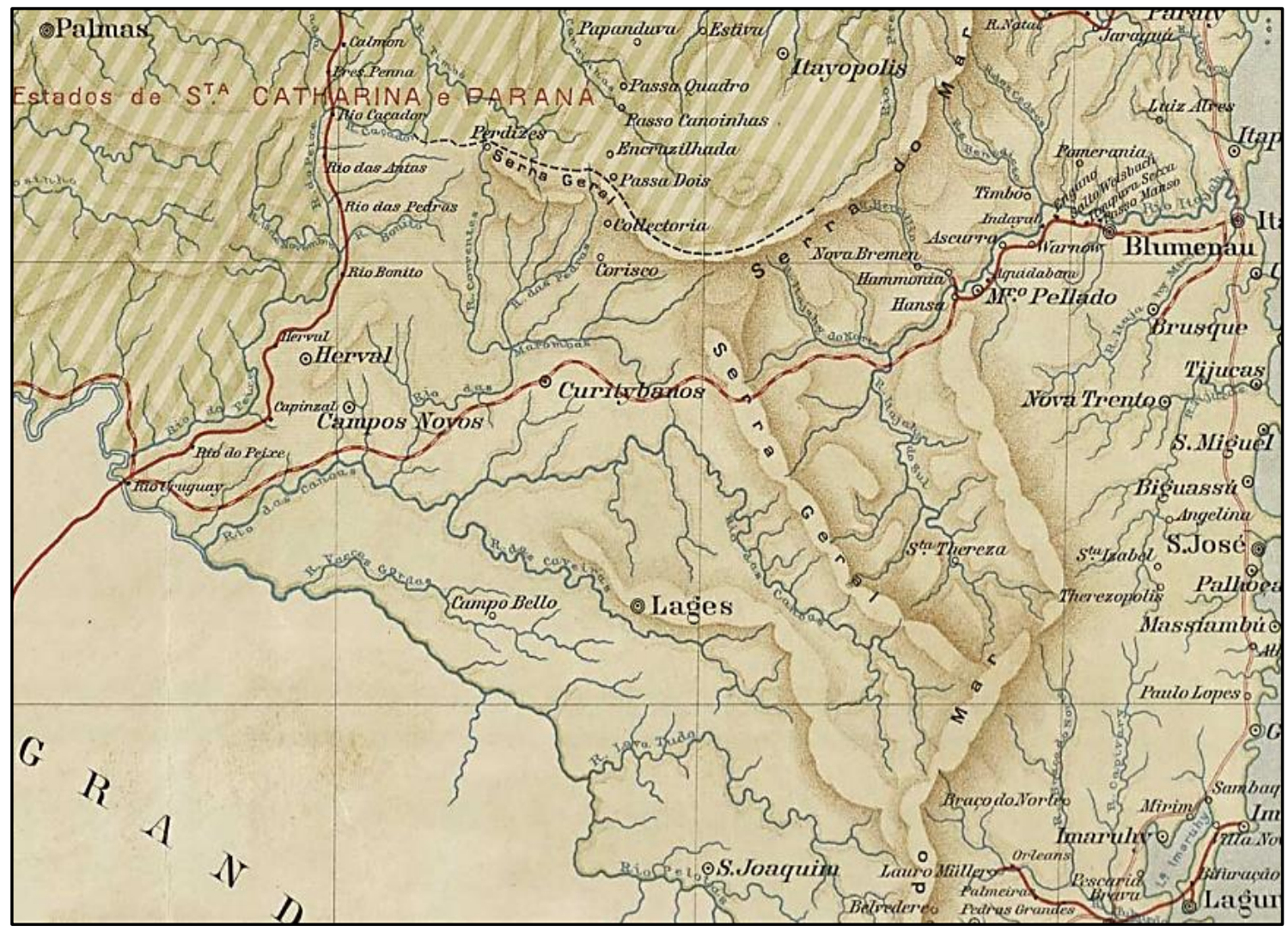

Detalhe do mapa Estados do Paraná e S. Catharina, de 1914. Inspetoria Federal das Estradas. Acervo da Biblioteca Nacional Digital. Endereço acessado em 13/05/2015. http://objdigital.bn.br/objdigital2/acervo_digital/div_cartografia/cart537520/cart537520.jpg 
Lages foi incorporada da administração provincial de São Paulo à província de Santa Catarina em 1820. Faziam parte do termo de Lages no século XIX as freguesias de Nossa Senhora do Patrocínio dos Baguaes (atual Campo Belo), São João Batista dos Campos Novos (atual Campos Novos), São Joaquim do Cruzeiro da Costa da Serra (atual São Joaquim) e Nossa Senhora da Conceição de Coritybanos (atual Curitibanos), sendo a vila de Lages a sede política da região, ${ }^{33}$ conforme é evidenciado no mapa acima.

Até 1822, a distribuição das terras no Brasil era realizada pela concessão de títulos de sesmaria outorgados pela Coroa e o presidente da província. Contudo, existiram diversas formas interpessoais de acesso à terra que, no planalto catarinense, contribuíram para a ocupação da região e o estabelecimento de novas fazendas, dando continuidade à expansão das concessões de sesmarias nas áreas de campos ao longo do século XIX, principalmente através de apossamento de terras devolutas, de sitiantes e de indígenas.

Muitos proprietários que possuíam títulos de sesmarias não demarcadas, além de grandes posseiros que se apropriaram de extensas faixas de terra entre o fim da legislação colonial e a nova legislação imperial, valeram-se da ausência de uma estrutura legal de regularização fundiária para ampliarem suas propriedades sobre terras públicas e de pequenos posseiros e sitiantes de forma fraudulenta, por meio de apossamentos e grilagens. Este contexto gerou distintas formas de domínio e usufruto da terra. Segundo José de Souza Martins, "não era raro o fazendeiro encontrar no território que se tornara sesmeiro, posseiros instalados com suas roças e ranchos". ${ }^{34}$ No planalto catarinense, estes posseiros estabeleceriam suas fazendas de criação, muitos pelo sistema de condomínio, por vezes dependendo de fazendeiros ou grandes criadores para permanecerem nas terras ocupadas sob a condição de agregados em concessões "de favor".

A província de Santa Catarina administrou o acesso e a distribuição de terras devolutas segundo as disposições do Ministério dos Negócios do Império instituído em 1823, e do Ministério da Agricultura, Comércio e Obras Públicas de 1861. Após o vácuo legislativo de 1822 até 1850 , o Decreto $n^{\circ} 1.318$ de 30 de Janeiro de 1854 regulamentou a execução da Lei de Terras e normatizou os processos de concessão e regularização fundiária no Império. ${ }^{35}$

No que concerne ao Rio Grande do Sul, Cristiano L. Christillino afirma que a burocracia fundiária e a aplicação da Lei de Terras estavam inseridas no projeto régio de centralização política, cuja estrutura empregatícia estava submetida a relações clientelísticas. ${ }^{36}$ Segundo ele, 
A centralização política empreendida pela Coroa não contava, inicialmente, com bases totalmente sólidas; dessa forma, a arbitragem sobre divergências regionais lhe trouxeram enormes vantagens políticas na medida em que estas se constituíram num verdadeiro poder de barganha junto a tais. Isto reforça a busca de inserção na estrutura clientelística do Estado, por parte das elites locais, intensificando o mesmo mecanismo, que, por sua vez, afirmava o poder da Coroa. ${ }^{37}$

Num contexto de precariedade de grande parte dos títulos de sesmaria, de posse legal e de sobreposição de diversas formas de acesso à terra, além de conflitantes noções do direito e acerca da legislação agrária, as relações sociais contribuíram sobremaneira, seja através da esfera judicial ou de forma interpessoal para a regularização fundiária no império. Márcia Motta considera o conflito pela terra um dos principais elementos estruturantes do território no Brasil que, segundo Christillino, foi em grande parte "mediado" pelo clientelismo político na esfera local, ligada, direta ou indiretamente, à presidência da província e ao Governo Central. Segundo Motta,

O Estado operou na dinâmica local no sentido de permitir a fluidez das fronteiras internas, não impondo uma regularização fundiária que delimitasse claramente as fazendas e os sítios. Assim sendo, a perpetuação de conflitos permitia que ele [Governo Imperial] assegurasse sua presença na consagração da fronteira nacional sem ferir os interesses dos terratenentes no jogo de poder para a criação/recriação das fronteiras internas. ${ }^{38}$

Este projeto de afirmação política imperial, empreendido no Segundo Reinado, descentralizou as atividades de regularização fundiária nas províncias e permitiu a flexibilização da lei de acordo com os interesses econômicos do poder local.

Na obra intitulada Clientelismo e política no Brasil do século XIX, o historiador Richard Graham afirma que, quem usufruía o poder local "tinha condições de atrair uma clientela em primeiro lugar a partir do fato de possuírem terras, ainda que nem todos os proprietários se envolvessem da mesma maneira na política municipal". ${ }^{39}$ Segundo Graham,

Os líderes locais precisavam de nomeações para cargos de autoridade, a fím de estender sua clientela e avançar na escala do poder e status. Ao mesmo tempo, o primeiro-ministro dependia da influência desses homens, mesmo na mais remota vila dos sertões, para reforçar o poder do governo central. ${ }^{40}$

No que concerne à aplicação da política fundiária do governo imperial, o Decreto n 1.722 de 09 de Fevereiro de 1856 outorgou a criação de Repartições Especiais de Terras Públicas em Pernambuco, Bahia e Santa Catarina. Além do trabalho dos funcionários da Repartição Especial de Terras Públicas, o Regulamento de 1854 deliberou que juízes de direito, juízes municipais, delegados, subdelegados e juízes de paz contribuíssem para o 
serviço de discriminação de terras públicas nas regiões sob suas jurisdições, informando sobre a existência de posses passíveis de legitimação e de sesmarias para revalidação. Os artigos 11, 28 e 30 tratam dos funcionários convocados para cada distrito e do serviço dos agentes públicos locais no que concerne à discriminação das terras devolutas nas jurisdições, respectivamente:

Em cada districto haverá hum Inspector Geral das medições, ao qual serão subordinados tantos Escreventes, Desenhadores, e Agrimensores, quantos convier. O Inspector Geral será nomeado pelo Governo, sob proposta do Director Geral. Os Escreventes, Desenhadores, e Agrimensores serão nomeados pelo Inspector Geral, com approvação do Presidente da Provincia.

[...] Logo que for publicado o presente Regulamento, os Presidentes das Provincias exigirão dos Juizes de Direito, dos Juizes Municipaes, Delegados, Subdelegados, e Juizes de Paz informação circumstanciada sobre a existencia, ou não existencia em suas Comarcas, Termos e Districtos de posses sujeitas á legitimação, e de sesmarias, ou outras concessões do Governo Geral, ou Provincial sujeitas á revalidação [...]. Obtidas as necessarias informações, os Presidentes das Provincias nomearão para cada hum dos Municipios, em que existirem sesmarias, ou outras concessões do Governo Geral, ou Provincial, sujeitas á revalidação, ou posses sujeitas á legitimação, hum Juiz Commissario de medições. ${ }^{41}$

Ao atribuir a tutela das terras devolutas para grupos de elite articulados ao poder local, o governo imperial permitiu que eles usufruíssem da possibilidade de ampliar seu próprio patrimônio e representação política. As inúmeras brechas presentes no Regulamento de 1854 possibilitaram a intervenção destes funcionários responsáveis pelos processos de legitimação de posses e revalidação de sesmarias, na ingerência de permutas em redes de poder locais nas quais estavam envolvidos grandes posseiros e proprietários, militares e comerciantes.A concentração de seus domínios possibilitava também a comercialização e a exploração da terra e dos recursos naturais, muitas vezes atraindo trabalhadores sem terra sob a condição de agregados e peões. Conforme Graham, "a força política do chefe local se originava, sobretudo, desse fato [concentração das terras]. Os clientes o procuravam por causa de sua riqueza agrária e ele era capaz de conservar e estender suas propriedades por que os comandava". ${ }^{42}$ É através desta estrutura burocrática da Lei de Terras instalada nas localidades que as redes de clientelismo se efetivaram e consumaram o projeto de centralização política, bem como a manutenção do próprio status quodecorrente da monopolização da propriedade fundiária.

Em relação à província de Santa Catarina, mais precisamente sobre a região do planalto que, no século XIX, concentrava a estrutura administrativa no termo de Lages, a articulação política e clientelística de grandes fazendeiros, criadores e negociantes esteve presente na burocracia da aplicação da Lei de Terras. A maioria dos funcionários era dotada 
de patentes militares na Guarda Nacional e ocupava alternadamente cargos judiciais e administrativos na comarca e no município. Todavia, a existência destas redes clientelísticas na estrutura burocrática do serviço de regularização fundiária do planalto não impossibilitou que pequenos posseiros e sitiantes pobres recorressem ao escrivão local e à legislação vigente na tentativa de validação de seus apossamentos, assim como não solidificou um acordo integral e monolítico entre as elites locais e o governo central.

Na década de 1850, a província de Santa Catarina possuía as câmaras municipais de Laguna, Desterro, São José, São Francisco, São Miguel, Porto Belo e Lages. Em 1854, o presidente da câmara de Lages era o tenente-coronel da Guarda Nacional, Manoel Rodrigues de Souza, ${ }^{43}$ um dos fundadores do Partido Conservador na região; e o secretário era Guilherme Ricken, ${ }^{44}$ que ocupara o cargo de delegado de polícia do município em 1852 . Este foi condecorado como Cavaleiro da Ordem da Rosa pelo Imperador quando o mesmo visitou a província. $^{45}$

Existia um chefe de polícia para cada província, que contava com seus delegados nos municípios e com subdelegados nos distritos. Segundo José Murilo de Carvalho, os delegados e subdelegados "tinham poder para dar buscas, prender [...] e conceder fiança. Eram eles que dividiam os distritos de paz em quarteirão, nomeavam inspetores [...] e os escrivães de paz e ainda faziam as listas de jurados. Essa situação durou até 1871 [...] quando foram tiradas as atribuições judiciárias". 46

O juiz municipal de Lages em 1854 era Francisco Borges do Amaral e Silva. ${ }^{47} \mathrm{O}$ Regulamento de 1854 atribuiu aos juízes municipais papel importante no processo de regularização fundiária. serviam em um termo ou município, e estavam sujeitos à interferência do juiz de direito de comarca, este nomeado pelo Ministério do Império. Ambas as funções demandavam formação jurídica. ${ }^{48}$ Cada juiz possuía seis substitutos (suplentes), homens locais eleitos conforme o montante de seus bens e as "boas relações", que não necessitavam de formação jurídica para o cargo. Era comum o juizado municipal permanecer vago por longos períodos e os suplentes assumirem a realização das atividades de esfera judicial. Assim, o sistema jurídico imperial contribuiu para as relações de apadrinhamento e clientelismo do Governo Central.

No que concerne à Guarda Nacional, após 1850, a concessão de patentes era realizada ou pelo presidente de província ou pelo ministro da justiça,dependendo do nível hierárquico. A mais alta patente era a de coronel, como a de ambos os presidentes da câmara de Lages de 1854 e 1857. 
De 1861 a 1863 retornou ao cargo de presidente da câmara de Lages o tenentecoronel Manoel Rodrigues de Souza, e foi substituído por Manoel Joaquim Pinto ${ }^{49}$ por apenas dois meses. Este tratava-se de um grande estancieiro paulista instalado na região de Lages e um dos organizadores da freguesia de São Joaquim do Cruzeiro da Costa da Serra. O secretário da câmara, na legislatura de 1861, era Antonio Saturnino de Souza Oliveira, ${ }^{50}$ major do $4^{\circ}$ Corpo de Cavalaria da Guarda Nacional de Lages e reformado como $2^{\circ}$ tenente de $1^{a}$ Linha. Antonio Saturnino também exerceu o cargo de delegado de polícia de Lages ainda em 1843 e foi $2^{\circ}$ suplente do juizado municipal em 1854, deputado provincial entre 1850-51 e 1856-57, além de vereador da câmara municipal em 1872. Casado com a filha de Manoel Rodrigues de Souza (o mesmo presidente da câmara e tenente-coronel da Guarda Nacional de Lages), Antonio Saturnino foi um dos chefes do Partido Conservador no município. ${ }^{51}$

O bacharel Francisco Carlos Araújo Brusque foi nomeado em 1859 por carta imperial à presidência de Santa Catarina, e foi um dos mais ativos presidentes no trabalho de deferimento de pedidos de vendas e concessões de terras devolutas, segundo foi possível observar no conjunto de requerimentos do planalto. Ex-deputado das Assembleias Provincial e Geral (esta pelas províncias do Rio Grande do Sul e Amazonas), Araújo Brusque posteriormente presidiu a província do Pará e os ministérios da Marinha e da Guerra.

É cabível considerar uma linha tênue de negociação constante entre o governo imperial e as elites locais, a partir da alternância entre os partidos Conservador e Liberal nos cargos municipais e entre as nomeações para a presidência provincial. Considerando a precariedade dos serviços da estrutura burocrática em uma província de baixo orçamento como Santa Catarina nos anos oitocentos e, especificamente, em uma região de grandes extensões fundiárias como o planalto, é possível refletir e questionar sobre quem, de fato, detinha o poder e de que forma executava-o.

Durante a vigência do período imperial foram recorrentes os pedidos de ampliação de prazos para legitimação e revalidação de posses e sesmarias pelos presidentes de província, sob a justificativa de atrasos no andamento dos trabalhos em função do baixo número de funcionários da Repartição Especial. Até que ponto esta morosidade nas medições e demarcações de terras não foi utilizada como estratégia para uma "desejada" desordem do cadastro de terras possuídas e para o avanço de práticas de grilagens e açambarcamento de terras devolutas e de sitiantes?

A Repartição Geral das Terras Públicas foi extinta em 1861, em função desta citada dificuldade de execução da Resolução de 1854, e suas atribuições foram transferidas 
para a $3^{\text {a }}$ Diretoria de Terras Públicas e Colonização - órgão da Secretaria dos Negócios do novo Ministério da Agricultura, Comércio e Obras Públicas. Foram mantidas as Delegacias Especiais de São Paulo, Espírito Santo, Paraná, Rio Grande do Sul e Santa Catarina, províncias que tencionavam receber cada vez mais imigrantes europeus, mas estas foram sendo, também, paulatinamente suspensas no decorrer dos anos seguintes.

A comissão de engenheiros nomeados pelo Ministério da Agricultura para a província de Santa Catarina era composta por Frederico Belmonte Braukenhuns, Carlos Felippe Garçon Rivière e Benno de Frakenberg Ludwegsdorf. Tanto o Ministério da Agricultura quanto o presidente da província realizaram diversas nomeações de comissões de engenheiros para trabalhos de medição e demarcação de lotes em colônias litorâneas de imigrantes europeus como Araranguá, Tubarão, Itajaí, Blumenau e Príncipe Dom Pedro. Em vista do exposto, é possível afirmar que a limitada eficiência dos serviços, tanto da Repartição e da Diretoria de Terras e Colonização quanto da Inspetoria Especial de Terras Públicas em Santa Catarina restringiu-se, grosso modo, à administração do assentamento de imigrantes estrangeiros em terras devolutas da província.

Ainda em relação à composição da estrutura burocrática da província de Santa Catarina, e mais especificamente do governo local instalado no planalto, em 1865 o presidente da câmara de Lages era José Marcelino Alves de Sá, ${ }^{52}$ fazendeiro, criador e coronel da Guarda Nacional do município. O escrivão era o capitão Antonio Ricken de Amorim, ${ }^{53}$ que também ocupou o cargo de promotor público da comarca. O juiz de direito era o bacharel Fernando Affonso de Mello, ${ }^{54}$ Cavaleiro da Imperial Ordem da Rosa, que atuou no mesmo cargo de juiz e como promotor público em outras diferentes comarcas do Império. Affonso de Mello foi acusado de tentativa de homicídio contra o presidente da câmara Alves de Sá, ${ }^{55}$ fato que nos permite inferir a existência de fissuras e disputas internas no âmbito da politicagem local. O $1^{\circ}$ suplente do juizado municipal era Henrique Ribeiro de Córdova, ex-presidente da câmara e deputado provincial.

Em 1860, o delegado da Repartição Especial das Terras Públicas e Colonização de Santa Catarina era o coronel João de Souza Mello Alvim, substituído em1863 pelo tenentecoronel da Guarda Nacional de Desterro José Bonifácio Caldeira de Andrada. ${ }^{56}$ Este, já havia exercido diversos cargos públicos por nomeação de carta imperial em outras províncias, além de haver sido deputado da Assembleia Legislativa Provincial de Santa Catarina em nove legislaturas, de 1842 à 1871, juiz de paz em São José (onde seu sogro, o comandante João Viera da Rosa era presidente da câmara), e comendador das imperiais ordens de Cristo e da 
Rosa. ${ }^{57}$ O fiscal interino da mesma Repartição era o bacharel Eleutério Francisco de Souza, que também exerceu os cargos de procurador fiscal da provedoria da província, subdelegado de polícia de Desterro em 1848, promotor público da Comarca do Norte, deputado da Assembleia Legislativa Provincial entre 1856 à 1869, vereador da câmara municipal de Desterro etc. ${ }^{58}$ Como se pode observar, ocupavam os cargos da Repartição de Terras na província apenas homens de considerável envergadura política, o que evidencia a importância das atividades da própria Repartição na política imperial.

O delegado José Bonifácio Caldeira de Andrada faleceu em 1870, ano em que o governo imperial extinguiu a Repartição Especial de Terras Públicas e Colonização de Santa Catarina e transferiu suas atribuições para a presidência provincial. Francisco Luiz da Silveira assumiu a delegacia da Repartição antes da extinção, ${ }^{59}$ sendo o fiscal o bacharel Olympio Adolfo de Souza Pitanga, ex-secretário do governo da província e fiscal do Tesouro da Fazenda provincial em 1860 e 1865, ex-diretor geral de instrução pública em 1863, deputado da Assembleia Legislativa Provincial de 1866 à 1881, ex-diretor da colônia Itajahy-Brusque e presidente do diretório do Partido Liberal em Santa Catarina etc. ${ }^{60}$

Em 1875 foi criada a Inspetoria Geral das Terras e Colonização pelo Ministério da Agricultura. O decreto $\mathrm{n}^{\circ} 6.129$ de 23 de Fevereiro de 1876, regulamentou as disposições de seu funcionamento nas províncias. Desde a extinção da Repartição Especial em 1870, até 1875, o trabalho de medição de terras devolutas em Santa Catarina era executado por comissões de engenheiros nomeados pelo presidente da província e pelo Ministério da Agricultura. Os engenheiros eram remanejados entre diferentes províncias, assim como os juízes comissários de terras.

Em 1870, o juiz comissário de Lages era o coronel-engenheiro-geógrafo matogrossense Francisco Antonio Pimenta Bueno, ${ }^{61}$ filho do Marquês de São Vicente (do núcleo Saquarema do Partido Conservador), ex-presidente da província do Amazonas, oficial da Ordem da Rosa e cavaleiro das ordens de Aviz e do Cruzeiro. É importante que reflitamos sobre o poder de um cidadão desta envergadura política frente à população e até mesmo aos políticos locais do planalto. Já em 1871 foi nomeado para o mesmo cargo Frederico Xavier de Souza, ${ }^{62}$ que havia trabalhado como juiz comissário em diferentes municípios da província como São José, Tijucas e Itajahy. O agrimensor era Augusto Moreira da Silva, que desempenhou o cargo até as primeiras décadas do período republicano. Em 1873, o juiz comissário era Cirillo Lopes de Haro, e em 1875 era Manoel José de Freitas Cardozo, que em 1878 foi exonerado e remanejado para o município de São José; no lugar deste, foi nomeado 
Constâncio Carneiro Barbosa de Brito $^{63}$ e posteriormente, João da Silva Ribeiro, outro tenente-coronel da Guarda Nacional. Também exerceram o cargo entre 1875 e 1877 Henrique Frederico Buys e Constâncio Carneiro Barboza de Brito.

Em 1880 havia em toda a província apenas sete juízes comissários para a execução dos trabalhos de medição e demarcação de terras devolutas e de legitimação de posses. Estes mesmos juízes normalmente tinham seu tempo de serviço prorrogado nas respectivas regiões em exercício e eram constantemente dirigidos a diferentes municípios da província conforme a necessidade de medições e demarcações, principalmente em áreas litorâneas de colonização europeia. Em 1882 o juiz comissário de Lages era aquele efetivado em Curitibanos, Caetano José de Souza. Em 1884, o juiz comissário do município de Curitibanos era Julio Xavier Nunes. O conjunto de requerimentos analisados na terceira parte deste trabalho indica que José de Souza e Xavier Nunes atuaram na municipalidade de Lages como juízes comissários simultaneamente, bem como Clementino Alves de Assumpção Rocha $^{64}$ em Curitibanos no referido ano.

Em 1885 foi nomeado pela portaria do Ministério da Agricultura de 31 de outubro, para o cargo de Inspetor Especial de Terras e Colonização da província de Santa Catarina o engenheiro agrimensor João Carlos Greenhalgh, além dos engenheiros Reginaldo Candido da Silva, como ajudante, e Antonio Carlos Rodrigues Lima e Trajano Pereira Brasil, ${ }^{65}$ como agrimensores. Foi removido do cargo de auxiliar da Comissão Hidráulica do Maranhão para escriturário da mesma Inspetoria na província o engenheiro João Evangelista Carneiro da Cunha, logo promovido a agrimensor, e nomeados para os cargos de escriturário João Cabral de Mello, Francisco Emilio do Livramento e o engenheiro Urbano Coelho de Gouvêa. $^{66}$

Em 1887, Greenhalgh foi exonerado do cargo de Inspetor Especial, sendo indicado para substituí-lo o engenheiro Augusto Fausto de Souza Junior. ${ }^{67}$ Este também foi substituído pelo engenheiro Joaquim Saldanha Marinho Filho em 1889. Os escriturários da Inspetoria Especial eram Marcos Antonio de Souza Aragão e Carlos Jansen Jr., e o agrimensor era Alfredo Aurélio de Figueiredo.

No que concerne a Lages, existiu a troca anual dos juízes comissários em exercício nos anos finais do regime monárquico, a saber, em 1886 o engenheiro Hercílio Pedro da Luz, ${ }^{68}$ em 1887 Diogo Duarte Silva da Luz, ${ }^{69}$ em 1888 João José Theodoto da Costa e em 1889 João José Godinho, substituído por Aureliano d'Oliveira Ramos. ${ }^{70}$ Em carta enviada ao incipiente governo republicano do Estado no ano de 1889, Oliveira Ramos 
afirmou que "ainda não estão discriminadas todas as terras em poder dos posseiros, que gosão [sic] das disposições da lei no 601 de 18 de Setembro de 1850", 71

A relativa autonomia concedida aos camaristas através das redes clientelistas efetuadas entre os poderes local, provincial e central, permitiu que estes funcionários e aqueles da Repartição Especial desenvolvessem os serviços de regularização fundiária de forma morosa e desorganizada, visto que este aspecto de "bagunça" na aplicação da lei contribuiu sobremaneira para a concentração fundiária e da riqueza de uma minoria estabelecida na região do planalto, ao passo que, no limiar do regime republicano, Santa Catarina pouco havia avançado no que tange à regularização fundiária.

\section{Requerimentos de compra de terras devolutas do termo de Lages}

Este estudo foi realizado a partir da análise de Requerimentos de compra de terras devolutas de Lages, Curitibanos e Campos Novos, disponíveis para pesquisa no Arquivo Público do Estado de Santa Catarina (APESC). Estão sistematizados no conjunto de 195 volumes intitulado Requerimentos: concessões de terras, cujo período se estende de 1836 a 1926,e estão organizados por ordem cronológica e localidade. Ao todo, constam 24 requerimentos das cidades supracitadas no período Monárquico, selecionados a partir do recorte temporal de 1850-1889.

As fontes empíricas evidenciam que os processos de regularização fundiária foram permeados pelas especificidades da região de análise: por se tratar de uma fronteira agrícola e de povoamento em expansão no século XIX, o planalto catarinense foi ocupado de diferentes maneiras, que repercutiram em diversos agenciamentos e estratégias de regularização da terra.Enquanto ficção jurídica, a propriedade foi construída e reconhecida socialmente.

Apesar da incompletude de grande parte dos autos dos requerimentos ter dificultado alguns aspectos deste estudo, foi verificado que a Lei de Terras não foi renunciada por fazendeiros e tampouco por pequenos posseiros na província de Santa Catarina. Ao contrário, ela constituiu um dinâmico campo de expectativas e disputas sobre diferentes concepções de direito e justiça, como consequência das diversas e complexas formas de ocupação de terra; num contexto de precariedade de muitos títulos de sesmaria e de legitimação, de sobreposição de diferentes posses e modos de ser posseiro. 
No que se refere às origens das ocupações de terra e às estratégias de validação de propriedade, foi observado que cerca de $41 \%$ dos requerimentos analisados solicitaram a compra de parcelas de terras públicas já ocupadas. Grandes e pequenos posseiros procuraram validar atos possessórios como argumento jurídico para o deferimento de pedidos de compra de posse, o que reflete a manutenção de alguns dos principais preceitos da legislação sesmarial, que previam a regularização de terras ocupadas e empregadas com trabalho agrícola. Também foram constatadas ocupações de terras devolutas seguidas de requisições de compra em condomínio, assim como a estratégica utilização do espaço de denominação dos confrontantes para a afirmação ou negação de direitos de propriedade, esta última, muitas vezes, agenciada entre pequenos posseiros nacionais contra abastados fazendeiros locais e juízes comissários de terras.

A presença de posseiros nacionais pobres, sitiantes e lavradores foi evidenciada com o percentual de $37 \%$ dos requerimentos com declarações de condição de pobreza, assinadas pelo vigário e vereadores municipais juntamente com afirmações de grupos familiares numerosos e a dependência do labor na terra para subsistência. Cerca de 45,8\% dos requerentes eram analfabetos, e estavam subordinados a familiares ou ao escrivão municipal para a assinatura a rogo. A análise qualitativa de alguns dos requerimentos indica que a migração interprovincial e a ocupação de terras devolutas nas florestas do interior constituíram estratégia de sobrevivência e relativa autonomia desta população pobre frente a chefes locais.

O clientelismo político e as possibilidades de politicagem e peculato foram observados com base no emparelhamento de grandes senhores e possuidores de terras em diversos escalões do estado, em cargos administrativos, policiais, jurídicos, de tabelionato (muitos dos quais como rábulas), etc.; e na aparência de isonomia presente nos procedimentos administrativos dos escrivães, atinando para o discurso indireto incitado nos requerimentos e para as possíveis margens de manobra no sentido de auto beneficiamento decorrente do gerenciamento das terras devolutas; visto que eram os vereadores juntamente com o juiz comissário de terras e fiscal que informavam quais terras eram devolutas na jurisdição local aptas à venda, por exemplo. A imprecisão da extensão dos lotes solicitados em grande parte dos requerimentos contribuiu para o processo de concentração fundiária desta minoria que compunha e geria, de forma bastante autônoma, o funcionalismo público no século XIX. Inclusive, foi constatada a criação de históricos dominiais, no intuito de garantir a anuência das compras de lotes, com a conivência de camaristas municipais. 
O estudo indica também que muitas querelas de terra procuraram ser resolvidas administrativamente por meio dos requerimentos de compra de terras devolutas e posses, remetidos ao presidente provincial,haja vista a recorrência de protestos de medição e de reclamações de compra de posses, sob acusações de invasão de propriedade, presentes em torno de $25 \%$ das solicitações. Desta forma, o presidente e camaristas municipais estavam habilitados também com poderes judiciais, ao ter de interferir e posicionar-se frente a situações de conflitos pela terra.

Todos estes requerimentos estavam relacionados, de algum modo, a atos possessórios (como cultura efetiva e morada habitual) conflitantes.Aproximadamente 54\% dos documentos analisados afirmaram a produção das lavouras de milho, feijão e fumo (ou as tinham como finalidade) e, numa porcentagem menor, a existência de plantio integrado à criação animal, com as espécies suína e de gado vacum e cavalar.

O caráter das unidades produtivas requisitadas por via de compra não refletia totalmente o perfil dos latifundiários pastoris existentes no planalto. A extensão das terras requeridas nos municípios de Lages e Campos Novos variaram entre 30,25 ha e 4.356 ha, e apresentaram áreas menores do que as observadas na região atual de Curitibanos, majoritariamente de 4.356 ha (que reproduzia o padrão de grandes propriedades).

Ademais, a existência de pequenos e médios lotes apossados e trabalhados em regime familiar, cuja principal produção era baseada em culturas características de subsistência, como milho e feijão, corrobora a afirmação de que havia diversos perfis de posseiros no planalto catarinense, durante o século XIX.

A questão nodal a ser ressaltada é que, a partir desta multiplicidade social de requerentes, existiram também estreitas e distintas formas de ocupação e de regularização da terra, que ultrapassam sobremaneira a norma jurídica outorgada em 1850 para todo o Império do Brasil, tendo em vista a compra (e não a legitimação) de terras públicas apossadas por ocupação simples após 1850, individualmente ou "em condomínio", muitos dos quais com atestados de pobreza anexados,práticas de grilagens, históricos dominiais inventados, conivência de funcionários da Inspetoria Especial com partes interessadas em compras ou legitimações de terras, resoluções de conflitos, etc. 


\section{Notas}

${ }^{1}$ TELLES, Bento da Silva; LEMOS, Estevão da Silva. Arquivo Público do Estado de Santa Catarina/APESC. [Requerimentos: concessões de terras T.C. = 1834 - 1840/41 - 1847 - 1855/56 - 1859/64 - 1867] 1859 jul., Campos Novos, vol. 01.Obs.: optou-se por manter a escrita original dos documentos manuscritos.

${ }^{2}$ Para um balanço historiográfico acerca da interpretação da Lei de Terras de 1850, vide, entre outros, MOTTA, Márcia Maria Menendes. "O embate das interpretações: o conflito de 1858 e a lei de terras". In: Revista Antropolítica. Niterói, nº4, 1998, pp.49-62; e SILVA, Lígia Osório. Terras devolutas e Latifúndio: efeitos da Lei de Terras de 1850. Campinas: Ed. UNICAMP, 1996.

${ }^{3}$ MARTINS, José de Souza. O cativeiro da terra. São Paulo: Hucitec, 1986.

${ }^{4}$ CARVALHO, José Murilo de, 1996, op. cit., pp. 303-325.

${ }^{5}$ Expressão proposta pela historiadora Márcia Maria Menendes Motta.

${ }^{6}$ MOTTA, Márcia Maria Menendes, 1998, op. cit., p. 58.

${ }^{7}$ HOLSTON, James. "Legalizando o ilegal: propriedade e usurpação no Brasill". In: Revista Brasileira de Ciências Sociais. N²1. São Paulo, 1993, p. 02.

${ }^{8}$ THOMPSON, Edward Palmer. Senhores e caçadores. Rio de Janeiro: Paz e Terra, 1987, p. 358.

${ }^{9}$ CONGOST, Rosa. Tierras, Leyes, Historia: "estudios sobre la gran obra de la propiedad". Barcelona: Crítica. 2007.

${ }^{10}$ Ibidem, passim, pp. 14, 20, 21, 22

11 LINHARES, Maria Yedda; TEIXEIRA DA SILVA, Francisco Carlos. Terra prometida: uma história da questão agrária no Brasil. Rio de Janeiro: Campus, 1999, p. 29.

${ }^{12}$ BOSI, Alfredo. "A escravidão entre dois liberalismos". In: Dialética da colonização. $3^{\text {a }}$ Edição. São Paulo: Companhia das Letras, 1992, pp. 04-39.

${ }^{13}$ HOLSTON, James, 1993, op. cit., p. 03.

${ }^{14}$ SILVA, Lígia Osório, 1996, op. cit., pp. 143-144.

${ }^{15}$ HOLSTON, James, 1993, op. cit., p. 18.

${ }^{16}$ Idem.

${ }^{17}$ BRASIL. Lei ${ }^{\circ}$. 601, de 18 de Setembro de 1850. Dispõe sobre as terras devolutas do Império. Disponível em: http://www.planalto.gov.br/ccivil_03/Leis/L0601-1850.htm. Acessado em 13 de Janeiro de 2015.

18 Idem.

${ }^{19}$ CONGOST, Rosa, 2007, op. cit., p. 21.

${ }^{20}$ LEVI, Giovanni. "Sobre a Micro-história”. In: BURKE, Peter (org.). A escrita da história: novas perspectivas. Tradução de Magda Lopes. São Paulo: Ed. da UNESP, 1992, pp. 135-136.

${ }^{21}$ Idem.

${ }^{22}$ GINZBURG, Carlo. A Micro-história e outros ensaios. Tradução de António Narino. Lisboa: DIFEL; Rio de Janeiro: Bertrand Brasil, 1991, pp. 177-178.

${ }^{23}$ MOTTA, Márcia Maria Menendes, 2008, p. 52.

${ }^{24}$ A palavra "posseiro" era utilizada no século XIX para contrapor a "sesmeiro”, ou seja, aquele que detém um título de sesmaria. Neste sentido, "posseiro" referia-se a todos os ocupantes sem título legal de terras.

${ }^{25}$ REVEL, Jacques. Jogos de escalas: a experiência da microanálise. Rio de Janeiro: FGV. 1998, p. 33.

${ }^{26}$ LEVI, Giovanni, 1992, op. cit., p. 155.

${ }^{27}$ Sobre o processo de colonização do Planalto Catarinense, vide, CABRAL, Oswaldo Rodrigues. História de Santa Catarina. $3^{\mathrm{a}}$ Edição. Florianópolis: Lunardelli, 1987; COSTA, Licurgo. O continente das Lagens: sua história e influência no sertão da terra firme. Florianópolis: Fundação Catarinense de Cultura, 1982; SANTOS, Sílvio Coelho. Nova história de Santa Catarina. $3^{a}$ Edição. Florianópolis: Terceiro Milênio, 1995; PIAZZA, Walter Fernando. A escravidão negra numa província periférica. Florianópolis: Garapuvu, 1999; EHLKE, Cyro. A conquista do Planalto Catarinense:bandeirantes e tropeiros do "Sertão de Curitiba". Rio de Janeiro: Laudes, 1973.

${ }^{28}$ MACHADO, Paulo Pinheiro, 2004, op. cit., p. 74.

${ }^{29}$ Para aprofundamento, vide, COSTA, Licurgo. Um cambalacho político: a verdade sobre o "acordo" de limites Paraná-Santa Catarina. Florianópolis: Editora Lunardeli, 1987.

${ }^{30}$ MACHADO. Paulo Pinheiro, 2004, op. cit., p. 69.

${ }^{31}$ Considerando o período de 1835-1845 como de grande instabilidade política na província vizinha em função da Revolução Farroupilha, bem como a participação de Lages, invadida em 1839.

${ }^{32}$ LEMOS, Zélia de Andrade. Curitibanos na história do Contestado. Florianópolis: Edição do Governo do Estado de Santa Catarina, 1977, pp. 75-76.

${ }^{33}$ Ao longo do século XIX as citadas freguesias emanciparam-se de Lages, a saber: Curitibanos em 1869, Campos Novos em 1881, São Joaquim em 1886. 
${ }^{34}$ MARTINS, José de Souza. Os camponeses e a política no Brasil: as lutas sociais no campo e seu lugar no processo político. $5^{\text {a }}$ Edição. Petrópolis: Editora Vozes, 1995, p. 35.

35 O Regulamento de 1854 foi disposto em nove capítulos intitulados: "Da Repartição Geral das Terras Públicas", "Da medição das terras públicas", "Da revalidação e legitimação das terras, e modo prático de extremar o domínio público do particular", "Da medição das terras que se acharem no domínio particular por qualquer título legítimo", "Da venda de terras públicas", "Das terras reservadas", "Das terras devolutas situadas nos limites do Império com países estrangeiros", "Da conservação das terras devolutas e alheias" e "Do registro das terras possuídas".

${ }^{36}$ CHRISTILLINO, Cristiano Luís. "A burocracia e a aplicação da Lei de Terras: o caso da Província de São Pedro do Rio Grande do Sul”. In: Revista Outros Tempos. Vol. 03, №. 03, 2006, pp. 133-155.

${ }^{37}$ Idem, p. 135.

${ }^{38}$ MOTTA, Márcia Maria Menendes. "Fronteiras internas no Brasil do século XIX”. In: Revista Vivência. № 33, 2008, pp.58.

${ }^{39}$ GRAHAM, Richard. Clientelismo e política no Brasil do século XIX. Rio de Janeiro: Ed. UFRJ, 1997, p. 167.

${ }^{40}$ Idem, p.101.

${ }^{41}$ BRASIL. Decreto $n^{\circ} 1.318$, de 30 de Janeiro de 1854. Manda executar a Lei $n^{\circ} 601$, de 18 de Setembro de 1850.Disponível em: http://www.planalto.gov.br/ccivil_03/decreto/Historicos/DIM/DIM1318.htm.Acessado em 13 de Janeiro de 2015.

${ }^{42}$ GRAHAM, Richard, 1997, op. cit., p. 41.

${ }^{43}$ BRASIL, Arquivo Público do Estado de Santa Catarina (BR, APESC). Inventário analítico dos ofícios das Câmaras Municipais para Presidentes de Província (1854-1857), volume 10, pp. 51-57.

${ }^{44}$ Idem.

${ }^{45}$ COELHO, Manoel Joaquim D'Almeida (Major). Memória Histórica da Província de Santa Catarina. Desterro [Florianópolis]: Tipografia Desterrense de J. J. Lopes, 1856.

${ }^{46}$ CARVALHO, José Murilo de, 1996, op. cit., pp. 137-138.

47 BRASIL, Arquivo Público do Estado de Santa Catarina (BR, APESC). Inventário analítico dos ofícios das Câmaras Municipais para Presidentes de Província (1854-1857), volume 10, pp. 51-57.

${ }^{48}$ GRAHAM, Richard, 1997, op. cit., p. 96.

49 BRASIL, Arquivo Público do Estado de Santa Catarina (BR, APESC). Inventário analítico dos ofícios das Câmaras Municipais para Presidentes de Província (1854-1857), volume 10, pp. 51-57.

${ }^{50}$ Idem.

${ }^{51}$ PIAZZA, Walter Fernando, 1994, op. cit., p. 498. Segundo Maria Regina Boppré, no ano de 1865, a câmara de Lages contava com apenas 11 eleitores, que votavam entre si para os cargos públicos. Ou seja, os postos burocráticos eram ocupados e concentrados pelas mesmas pessoas que acumulavam grandes propriedades na região, tendo em vista que o voto era censitário. Além disso, práticas de nepotismo também foram comuns.

52 BRASIL, Arquivo Público do Estado de Santa Catarina (BR, APESC). Inventário analítico dos ofícios das Câmaras Municipais para Presidentes de Província (1854-1857), volume 10, pp. 51-57.

${ }^{53}$ Idem.

${ }^{54}$ Idem.

${ }^{55}$ BRASIL. Annaes do Parlamento Brasileiro. Camara dos Srs. Deputados. Primeiro anno da décima-terceira legislatura sessão de 1867. Tomo 2. Rio de Janeiro: Typographia Imperial e Constitucional de J. Villeneuve \& C. 1867 , p. 231.

${ }^{56}$ BRASIL, Arquivo Público do Estado de Santa Catarina (BR, APESC). Registros de ofícios da Inspetoria Especial de Terras e Colonização para Presidentes de Província - 1865/69.

${ }^{57}$ PIAZZA, Walter Fernando, 1994, op. cit., pp. 55-56.

${ }^{58}$ Ibidem, p. 742.

${ }^{59}$ BRASIL. PROVINCIA DE SANTA CATARINA. Relatório que o exm. sr. presidente da província de Santa Catharina, dr. Joaquim Bandeira Gouvêa, dirigio á Assembleia Legislativa Provincial no acto da abertura da sua sessão ordinária em 26 de Março de 1871. Desterro: Typ. do Jornal, 1871, p. 13.

${ }^{60}$ PIAZZA, Walter Fernando, 1994, op. cit., p. 629.

${ }^{61}$ BRASIL. PROVINCIA DE SANTA CATARINA. Relatório apresentado pelo $2^{o}$ vice-presidente de Santa Catharina o Exm. Sr. Doutor Manoel do Nascimento da Fonseca Galvão ao presidente Exm. Sr. Doutor André Cordeiro de Araújo Lima por ocasião de passar-lhe a administração da mesma em 3 de Janeiro de 1870. Desterro: Typ. de J. J. Lopes, 1870, p. 16.

${ }^{62}$ Ibidem, p. 13. 


\footnotetext{
${ }^{63}$ BRASIL. PROVINCIA DE SANTA CATARINA. Relatório ao Exm. Sr. Dr. Joaquim da Silva Ramalho $1^{o}$ vice-presidente passou a administração da provincia de Santa Catarina ao Exm. Sr. Dr. José Bento de Araujo em 14 de fevereiro de 1878. Desterro: Tip. Regeneração de João Pinto n.20, 1878, p. 52.

${ }^{64}$ Assumpção Rocha era de uma conhecida família do norte de Curitibanos, região de Perdizes.

${ }^{65}$ BRASIL. PROVINCIA DE SANTA CATARINA, 1888, op. cit., p. 296.

${ }^{66}$ BRASIL. PROVINCIA DE SANTA CATARINA. Relatório apresentado à Assembleia Legislativa da Província de Santa Catharina na $1^{a}$ sessão de sua $26^{a}$ Legislatura pelo presidente Dr. Francisco José da Rocha em 21 de Julho de 1886. Desterro: Typ. do Conservador, 1886, p. 191.

${ }^{67}$ BRASIL. PROVINCIA DE SANTA CATARINA, 1888, op. cit., p. 294.

${ }^{68}$ BRASIL. PROVINCIA DE SANTA CATARINA. Relatório com que ao Exm. Sr. Coronel Manoel Pinto de Lemos $1^{o}$ vice-presidente passou a administração da província de Santa Catharina o Dr. José Lustosa da Cunha Paranaguá em 22 de Junho de 1885. Desterro: Typographia do Jornal do Commercio, 1885, p. 40.

${ }^{69}$ BRASIL. PROVINCIA DE SANTA CATARINA, 1888, op. cit., p. 333.

${ }^{70}$ BRASIL. PROVINCIA DE SANTA CATARINA. Relatório com que ao excellenptissimo Sr. Doutor Luiz Alves Leite de Oliveira Bello passa a administração da Provincia o Exm. Sr. Doutor Abdon Baptista $2^{\circ}$ vicepresidente em 19 de Julho de 1889. Desterro: Typographia do Democrata, 1890, p. 30.

${ }^{71}$ RAMOS, Aureliano de Oliveira. Ao ex.mo senhor governador do estado republicano de Santa Catarina. Arquivo Público do Estado de Santa Catarina/APESC. [Requerimentos: concessões de terras] 1889, dez., volume 23.
}

\section{Referências Bibliográficas}

BOGACIOVAS, Marcelo Meira Amaral. Antigas propriedades rurais de Lages. In: Revista da ASBRAP. São Paulo, nº, p. 9-92, 1999.

BOPPRÉ, Maria Regina. Eleições diretas e primórdios do coronelismo catarinense (18811889). Florianópolis: Secretaria de Estado da Administração, 1989.

BOSI, Alfredo. Dialética da colonização. $3^{\circ}$ Edição. São Paulo: Companhia das Letras, 1992. BORGES, Nilsen Christiani Oliveira. Terra, gado e trabalho: sociedade e economia escravista em Lages, SC, 1840-1865. Dissertação de Mestrado em História, Universidade Federal de Santa Catarina, 2005.

BRANDT, Marlon. Uma história ambiental dos campos do Planalto de Santa Catarina. Tese de Doutorado. Universidade Federal de Santa Catarina. Florianópolis, 2012.

CABRAL, Oswaldo R. História de Santa Catarina. $3^{\mathrm{a}}$ Edição. Florianópolis: Lunardelli, 1987.

CARDOSO, Ciro Flamarion Santana. Agricultura, escravidão e capitalismo. Petrópolis: Vozes, 1979.

CARVALHO, José Murilo de. A construção da ordem: a elite política imperial; Teatro de sombras: a política imperial. Rio de Janeiro: Ed. UFRJ/ Relume-Dumará, 1996.

Janeiro: Civilização Brasileira, 2007.

Nação e cidadania no Império: novos horizontes. Rio de

CHRISTILLINO, Cristiano Luís. "A burocracia e a aplicação da Lei de Terras: o caso da Província de São Pedro do Rio Grande do Sul”. In: Revista Outros Tempos. Vol. 03, № 03, 2006, pp. 133-155.

Litígios ao sul do Império: a Lei de Terras e a consolidação política da Coroa no Rio Grande do Sul (1850-1880). Tese de Doutorado. Niterói: UFF, 2010. CONGOST, Rosa. Tierras, Leyes, Historia: estudios sobre la gran obra de la propiedad. Barcelona: Crítica, 2007.

COSTA, Licurgo. Um cambalacho político: a verdade sobre o "acordo" de limites ParanáSanta Catarina. Florianópolis: Editora Lunardeli, 1987. 
. O continente das Lagens: sua história e influência no sertão da terra firme.

Florianópolis: Fundação Catarinense de Cultura, 1982.

EHLKE, Cyro. A conquista do Planalto Catarinense:bandeirantes e tropeiros do "Sertão de Curitiba". Rio de Janeiro: Laudes, 1973.

FARINATTI. Luís Augusto Ebling. Confins meridionais: famílias de elite e sociedade agrária na Fronteira Sul do Brasil (1825-1865). Santa Maria: Ed. da UFSM, 2010.

Apropriação da terra e formação de grandes patrimônios

na Fronteira Sul do Brasil, através de inventários post mortem (1800-1860). In: Trabajos y Comunicaciones. 2009, no. 35, pp. 149-171.

GARCIA, Graciela Bonassa. O domínio da terra: conflitos e estrutura agrária na Campanha Rio-Grandense oitocentista. Porto Alegre, UFRGS, PPGH, Dissertação de Mestrado, 2005.

Terra, trabalho e propriedade: a estrutura agrária da

Campanha Rio-Grandense nas décadas finais do Período Imperial (1870-1890). Niterói, Tese de Doutorado, 2010.

GINZBURG, Carlo. A micro-história e outros ensaios. Tradução de António Narino. Lisboa: DIFEL; Rio de Janeiro: Bertrand Brasil, 1991.

GRAHAM, Richard. Clientelismo e política no Brasil do século XIX. Rio de Janeiro: Ed. UFRJ, 1997.

HOLSTON, James. "Legalizando o ilegal: propriedade e usurpação no Brasil". In: Revista Brasileira de Ciências Sociais. № 21. São Paulo, 1993.

GRINBERG, Keila \& SALLES, Ricardo (org.). O Brasil Imperial:1870-1889. RJ: Civilização Brasileira, vol.03, 2009.

LEMOS, Zélia de Andrade. Curitibanos na história do contestado. Florianópolis: Edição do Governo do Estado de Santa Catarina, 1977.

LEVI, Giovanni. A herança imaterial: trajetória de um exorcista no Piemonte do século XVII. Tradução de Cynthia Marques de Oliveira. Rio de Janeiro: Civilização Brasileira, 2000.

. "Sobre a Micro-história". In: BURKE, Peter (org.). A escrita da história: novas perspectivas. Tradução de Magda Lopes. São Paulo: Edição da UNESP, 1992.

LINHARES, Maria Yedda; TEIXEIRA DA SILVA, Francisco Carlos. Terra prometida: uma história da questão agrária no Brasil. Rio de Janeiro: Campus, 1999.

LIMA, Ruy Cirne. Pequena História territorial do Brasil: sesmarias e terras devolutas. $2^{\mathrm{a}}$ Edição. Porto Alegre: Livraria Sulina, 1954.

MACHADO, Paulo Pinheiro. A política de colonização do Império. Porto Alegre: Editora Universidade UFRGS, 1999.

Lideranças do Contestado: a formação e a atuação das chefias caboclas (1912-1916). Campinas, SP: Editora da UNICAMP, 2004.

MACIEL, Janaína Neves. Terra, direito e poder: legislação estadual de Santa Catarina e a regularização da propriedade da terra em Lages, 1890-1910. Trabalho de Conclusão de Curso. Universidade Federal de Santa Catarina, 2013.

MARTINS, José de Souza. Fronteira: a degradação do outro nos confins do humano. São Paulo: Hucitec, 1997. O cativeiro da terra. São Paulo: Hucitec, 1986.

Os camponeses e a política no Brasil: as lutas sociais no campo e seu lugar no processo político.Petrópolis: Vozes, 1986.

MOTTA, Márcia Maria Menendes. Nas fronteiras do poder: conflito e direito à terra no Brasil do século XIX. $2^{\text {a }}$ Edição. Niterói: Editora da Universidade Federal Fluminense, 2008.

Vivência. № 33, 2008, pp. 55-65. "Fronteiras internas no Brasil do século XIX". In: Revista 
In: Revista Antropolítica. Niterói, nº4, 1998, pp.49-62.

. "O embate das interpretações: o conflito de 1858 e a lei de terras". ; GUIMARÃES, Elione Silva (org.). Propriedades e disputas: fontes para a história do oitocentos. Guarapuava: UNICENTRO; Niterói (RJ): EDUFF, 2011.

; SECRETO, Mária Verónica (org.). O direito às avessas: por uma história social da propriedade. Guarapuava: UNICENTRO; Niterói (RJ): EDUFF, 2011.

OSÓRIO, Helen. Apropriação da terra no Rio Grande de São Pedro e a formação do Espaço Platino. Porto Alegre, UFRGS-PPGH, Dissertação de Mestrado, 1990.

- Estancieiros do Rio Grande de São Pedro: constituição de uma elite terratenente no século XVIII. Actas do Congresso Internacional Espaço Atlântico de Antigo Regime: poderes e sociedades. Lisboa, 2005.

PIAZZA, Walter Fernando. O poder legislativo catarinense: das suas raízes aos nossos dias (1834-1984). Florianópolis: Assembleia Legislativa do Estado de Santa Catarina, 1984.

. Dicionário político catarinense. $2^{\mathrm{a}}$ Edição. Florianópolis: Edição

da Assembleia Legislativa do Estado de Santa Catarina, 1994.

REVEL, Jacques. Jogos de escalas: a experiência da microanálise.Rio de Janeiro: FGV, 1998.

SILVA, Lígia Osório. Terras devolutas e Latifúndio: efeitos da Lei de Terras de 1850. Campinas: Ed. UNICAMP, 1996.

THOMPSON, Edward P. Senhores e caçadores. Rio de Janeiro: Paz e Terra, 1987.

ZARTH, Paulo Afonso. História Agrária do Planalto Gaúcho (1850-1920). Ijuí: Editora da UNIJUÍ, 1997.

XIX. Ijuí: Ed. Uniijuí, 2002.

Do arcaico ao moderno:o Rio Grande do Sul agrário do século - (org.) História do Campesinato na Fronteira Sul. Porto Alegre: Letra \& Vida; Chapecó: Universidade Federal da Fronteira Sul, 2012. 